\title{
LEGAL BARRIERS IN THE BUSINESS OF BIOFERTILIZERS AND BIOPESTICIDES IN UKRAINE
}

\author{
PRÁVNE PREKÁŽKY \\ V PODNIKANÍ S BIOHNOJIVAMI A BIOPESTICÍDMI \\ NA UKRAJINE
}

\author{
Hasrat ARJJUMEND* - Konstantia KOUTOUKI* - Anatoly GETMAN** - Olga DONETS**
}

\section{Introduction}

Managing pests and improving soil fertility are key to increasing food availability. However, the unsustainable application of chemical fertilizers and plant protection chemicals have resulted in the steady decline of soil and crop productivities the world over. To overcome this challenge, rising food yields must be decoupled from the unsustainable utilization of water, fertilizers, chemicals, and land. Investing in sustainable agriculture is one of the most effective ways to simultaneously achieve the Sustainable Development Goals (SDGs) related to poverty and hunger, nutrition and health, education, economic and social growth, peace and security, and the preservation of the world's environment ${ }^{(1)}$. 'Biologicals' (biofertilizers and biopesticides) are microbial products that increase agricultural productivity, while also contributing to the soil's ability to produce more in the future. These microbes, fungi and other plant-derived products are relatively safe for human consumption. Small quantities of biologicals are often effective, and biofertilizers and biopesticides

(1) Earth Alive (2017).

\section{Abstract (EN)}

'Biologicals' (biofertilizers and biopesticides) are microbial products that increase agricultural productivity, while also contributing to soil health. These microbial products are relatively safe for human consumption. However, the legal registration of microbial products and the operation of businesses in this sector face barriers that affect the expansion and widespread use of these green products. A study of these barriers was conducted by researchers at the Université de Montréal, with the financial support of Mitacs and Earth Alive Clean Technologies, using participatory methods of semi-structured interviews, structured interviews and informal discussions with the manufacturers, suppliers and traders of biologicals, as well as the government officers dealing with biologicals in Ukraine. This article analyses the data collected from the participants concerning obstacles to the registration, licensing, and proliferation of microbial products.

\section{Keywords (EN)}

legal barrier, registration barrier, biopesticides, biofertilizers, license decompose quickly, leaving no footprint. However, the legal registration of microbial products and the operation of businesses in this sector face barriers that affect the expansion and widespread use of these green products.

In Ukraine, the 'Main State Inspection of Plant Protection' is the body responsible for the registration of biopesticides and all other plant protection products, as well as plant growth promoters and micronutrients. This body is also the main administrator of State trials, and it creates the annual State Register of allowable pest control products and regulates all the organizations and companies involved in the production, use, trade, transport, storage, disposal, and other activities along the post-registration value chain. There are 28 organizations and institutions involved in the certification and approval of pest control products. These organizations are also the main proponents of biopesticide research and development. Most of these organizations fall under the Research Institutes of the Ukrainian Agricultural Academy of Sciences (UAAN), National Academy of Sciences (NANU), or the various agricultural universities ${ }^{(2)}$.

(2) Anishchenko et al. (2010).

\section{Abstrakt (SK)}

„Biologické látky“ (biohnojivá a biopesticidy) sú mikrobiálne produkty, ktoré zvyšujú produktivitu polnohospodárskej výroby a súčasne prispievajú k zdraviu pôdy, pričom konzumácia týchto produktov je relatívne bezpečná. Zákonná registrácia mikrobiálnych produktov a prevádzka podnikov $v$ tomto sektore však čelia prekážkam, ktoré ovplyvňujú rozšírenie a využivanie týchto ekologických výrobkov. Analýzu bariér uskutočnili vedci z Université de Montréal za finančnej podpory spoločností Mitacs a Earth Alive Clean Technologies s využitím participatívnych metód pološtruktúrovaných rozhovorov, štruktúrovaných rozhovorov a neformálnych diskusií s výrobcami, dodávatel'mi a obchodníkmi s biologickými látkami, ako aj vládnymi úradníkmi zaoberajúcimi sa biologickými látkami na Ukrajine. Tento článok analyzuje údaje získané od respondentov týkajúce sa prekážok registrácie, licencií a šírenia mikrobiálnych produktov.

\section{Klưčové slová (SK)}

právne bariéry, registračné bariéry, biopesticídy, biohnojivá, licencia

\footnotetext{
* Centre for International Sustainable Development Law, Montreal (Quebec), Canada

** Yaroslav Mudryi National Law University of Ukraine, Ukraine
} 
Table 1

\begin{tabular}{|l|c|c|c|c|}
\hline \multicolumn{1}{|c|}{ Participant Group } & Sample Size & Names of Oblasts & Sampling Method & Research Method \\
\hline $\begin{array}{l}\text { G 1. Manufacturers and } \\
\text { Suppliers }\end{array}$ & 8 & $\begin{array}{c}\text { Lviv, Kiev, Ivano-Frankivsk, } \\
\text { Kharkiv, Chernihiv }\end{array}$ & Snowball, Purposive & $\begin{array}{c}\text { Semi-structured interview; } \\
\text { Structured interview }\end{array}$ \\
\hline G 2. Government Officers & 8 & $\begin{array}{c}\text { Lviv, Kiev, Ivano-Frankivsk, } \\
\text { Kharkiv }\end{array}$ & Purposive, Expert & $\begin{array}{c}\text { Informal discussion; } \\
\text { Semi-structured interview }\end{array}$ \\
\hline
\end{tabular}

With respect to biologicals, the major challenges for most countries revolve around inadequate legislation, lack of capacity, and weak implementation of policies related to biofertilizers and biopesticides ${ }^{(3)}$. Many countries have amended their policies to minimize the use of chemical pesticides and promote the use of biopesticides; however, biopesticides are still largely regulated by the system originally designed for chemical pesticides. This has created market entry barriers by imposing burdensome costs on the biopesticide industry ${ }^{(4)}$. Serious challenges in this regard include the relative immaturity of the policy network, limited resources and capabilities, and a lack of trust between regulators and producers.

Two groups of participants - manufacturers, suppliers and traders of biologicals, and government officers dealing with biologicals - were interviewed in 2018-19 using semi-structured interviews, structured interviews, and informal discussions. Variables such as the biological relevance and effectiveness of microbial products, and barriers to business and registration were studied. This article explores the perceptions and understanding of the participants concerning barriers to the registration, licensing, proliferation and business operation of microbial products. It is part of a larger study conducted between September 2017 and February 2020 by the authors at the Faculty of Law at the Université de Montréal, with the support of Mitacs and Earth Alive Clean Technologies, and field work support by Yaroslav Mudryi National Law University of Ukraine.

\section{Methodology}

Field research was conducted in Ukraine to understand barriers to the registration and licensing of biologicals, as well as the efficacy and efficiency of their monitoring. Primary data was gathered by interviewing participant groups, in addition to a desk review of the literature.

\section{Sampling and Sample Techniques}

This study was conducted by selecting two participant groups: Group 1 - Manufacturers and Suppliers; and Group 2 - Government Officers. Group 1 participants (listed in Appendix 1) are direct stakeholders who are affected by, and provided insights concerning, regulatory barriers concerning biologicals. Group 2 participants (listed in Appendix 2) are involved in policy/law implementation and enforcement. Some of the information shared by these officers was provided on an informal basis, as they cannot share such information in their official capacity. Table 1 contains the total sample size of each of the participant groups. After taking pre-appointments, in person interviews were conducted.

\footnotetext{
(3) Urs (2015).

(4) Kumar, Singh (2014).
}

Several sampling techniques were used to select the participants. The manufacturers/suppliers of biologicals (Group 1 participants) were sampled using purposive sampling and snowball sampling techniques (Table 1). Group 2 participants were sampled in each oblast of Ukraine using purposive sampling and expert sampling.

\section{Methods of Data Collection}

As mentioned in Table 1, different data collection methods were used to collect data from the two participant groups. Information from manufacturers/suppliers (Group 1 participants) was collected based on the questions listed in Table 2, using semi-structured and structured interviews (Table 1). Information from Group 2 participants was collected based on the questions listed in Appendix 3, using semi-structured interview and informal discussion methods (Table 1).

\section{Certificat d'approbation éthique (Ethical Approval Certifi-} cate)

The Multi-Faculty Committee on Research Ethics (Comité plurifacultaire d'éthique de la recherche - CPER) of the Université de Montréal issued an Ethical Approval Certificate (no. CPER-17-114-P) to the study project. The conditions of the Ethics Certificate were fulfilled during the collection of field data from all three participant groups. In compliance with the Ethics Certificate, a Consent Form was presented to each of the individual participants in Ukrainian, and was signed by both the participant and field researcher. Before conducting the interview or discussion with the participants/participants, each individual was informed of the objectives of the research through an Information Sheet containing participant expectations, the benefits of sharing information, details concerning confidentiality, and participants' right to withdraw. The collection of information commenced only once explanations concerning the research had been provided and the freely given consent of the participant/participant was obtained.

\section{Results and Discussion}

The present article seeks to understand the legal and procedural barriers impeding the microbial biofertilizer and biocontrol agent business, including the trials, storage, transport, sale, trade, import, manufacturing and exhibition of these products. The following discussion is based on an analysis of the responses given by the manufacturers/suppliers and government officers who were surveyed.

\section{Microbial Biofertilizers}

Biofertilizers are microbial compounds that enhance soil fertility by using microorganisms in symbiotic relationships with plants. More precisely, they can be defined as microbial in- 
oculants containing cultures of certain soil microorganisms that are multiplied under controlled conditions, and that can improve soil fertility and crop productivity ${ }^{(5)}$.[5] Biofertilizers can be classified broadly into eight types: (i) Rhizobium, (ii) Azospirillum, (iii) Azotobacter, (iv) Blue Green Algae (Cyanobacteria) and Azolla, (v) Mycorrhiza (Phosphate Absorbers), (vi) Plant Growth Promoting Rhizobacteria, (vii) Phosphate Solubilizers, and (viii) Zinc Solubilizers. Biofertilizers can also be classified by technology type (carrier-enriched biofertilizers, liquid biofertilizers, and other technology types), by application (seed treatment and soil treatment), and by crop type (cereals, legumes, fruits and vegetables, plantations, and other crop types).

\section{Biopesticides or Biocontrol Agents}

Biopesticides have minimal impact on non-target organisms. Possessing complex modes of action, they are not prone to resistance and they help reduce the development of resistance when used in resistance management programs. Biopesticides hold significant benefits for growers, offering:

- Pest control, thereby enhancing crop quality and yields

- Improved export opportunities, because most are residue exempt

- An improved environmental profile

- Organically approved status that allows organic growers to control pests while maintaining their certified status.

Biopesticides may be categorized as:

a) Biofungicides (e.g. Trichoderma viride, Pseudomonas fluorescence)

b) Bioinsecticides (e.g. Bacillus thuringiensis)

c) Bionematicide (e.g. Verticillium chlamydosporium)

\section{Types of Biologicals and their Effectiveness}

In Ukraine, manufacturers/suppliers were not able to identify the categories of biofertilizers present in the country (Table 2). This lack of knowledge may be because statutory bodies have not defined those categories; rather all plant growth stimulators, bio-stimulants, nutrition supplements, etc. are treated as agrochemicals. By contrast, participant manufacturers/suppliers identified two categories of biopesticides being manufactured or supplied/traded: biofungicides and bioherbicides. Toxicological tests of these biopesticides are conducted by authorized laboratories or research institutes to establish that they are harmless and increase immunity of plants and soil (Table 2). On the question of biosafety issues associated with biopesticides, the participant manufacturers/suppliers provided no response (Table 2).

\section{Barriers in the Registration and Certification Process}

With respect to the procedures for the registration of manufacturing, import, trade/sale, transport, storage, disposal, etc. of biofertilizers and biopesticides (Table 2), all of the participants surveyed commented on the lack of an adequate legal framework in Ukraine and on the existing corruption. They also noted the absence of a procedure for registering biofertilizers, for registering an enterprise, and for obtaining permits

(5) Roychowdhury, Paul, Banerjee (2014).
(Table 2). Some participants indicated that the procedure for registration is lengthy (sometimes up to two years), noting that a tremendous amount of data on phytosanitary parameters is required (Table 2), along with technical tests such as a passport of safety, phytosanitary and epidemiological data, bioassays and immunological tests. These tests are extremely hard to perform and comply with (Table 2). One participant stated that until 2009, biofertilizers did not require registration; however, since July 2015, registration has been required for plant growth promoters (Table 2). The documents required at the time of application include business registration, a permit from the Fire Department, waste disposal clearance, a sanitary passport for the warehouse, a copy of instructions for labour protection (labour rights and workplace safety), compliance for commercial premises, documents showing ownership, a certified copy of statistical reference, copy of an extract from the register of the Unified State Register of Enterprises and Organization of Ukraine (USREO), lease contract and statute, a letter of guarantee for the disposal of toxic waste, bank account of enterprise, copies of employees' diplomas, bank statements and tax compliance, quality certificates, test reports, evaluation by experts, and document containing names of workers (Table 2). In the opinion of the participant manufacturers/suppliers, the assistance of a lawyer is essential; otherwise, the registration process is more protracted (Table 2).

A large amount of data from laboratory tests and efficacy tests is required during the registration process (Table 2). This data pertains to biological, toxicological and ecological parameters. Once this registration is obtained by manufacturers, retailers or suppliers must also acquire certification from the manufacturer company in order to sell the products to farmers (Table 2). Similarly, international products require certificates on the part of foreign producers.

Responding to questions pertaining to a detailed account of the barriers at each step of the registration process, the surveyed manufacturers/suppliers indicated that the primary barriers are corruption, lack of a set procedure for the registration of biofertilizers, lack of a time-bound procedure, higher unofficial charges for registration, and the complexity of the registration process (Table 2). Moreover, there are several tests, such as the toxico-hygienic passport, that need to be obtained from specialized scientific institutions. Obtaining such tests and certifications is another barrier (Table 2). Finally, licenses are issued only three times a year, which is another barrier to registration (Table 2 ).

With respect to how biologicals are treated in comparison to chemicals, the participant manufacturers/suppliers commented that the terminology for biopesticide and biofertilizer legislation should be changed. They explained that as soon as a product is classified as a pesticide or fertilizer, the process of obtaining permits and licenses becomes complicated (Table 2). Biopesticide and biofertilizer words also comprise 'pesticide' and 'fertilizer', which attract the same treatment given to the microbial products despite the fact that these are not the chemicals and toxic.

The participant manufacturers/suppliers analyzed the costs involved at each step of the registration process (Table 2). They identified the long processing time as a significant cost; while the processing time to obtain a license without the help 
Table 2: Manufacturers, suppliers, importers and traders of microbial biofertilizers and biopesticides

\begin{tabular}{|c|c|}
\hline Questions & Responses - Ukraine \\
\hline \multicolumn{2}{|c|}{ What kinds of biologicals in what quantities with what effectiveness are being used by farmers? } \\
\hline $\begin{array}{l}\text { Categories of biofertilizers manufac- } \\
\text { tured or supplied/traded }\end{array}$ & - Microbes-based \\
\hline $\begin{array}{l}\text { Any efficacy or efficiency tests/data } \\
\text { of such biofertilizers? }\end{array}$ & $\begin{array}{l}\text { - Field trials result } 42 \% \text { increase of the yield of wheat. } \\
\text { - For all products stated tests were conducted. } 10-30 \% \text { increase in efficiency. }\end{array}$ \\
\hline $\begin{array}{l}\text { Categories of existing biopesticides } \\
\text { manufactured or supplied/traded }\end{array}$ & $\begin{array}{l}\text { - Biofungicide } \\
\text { - Herbicide }\end{array}$ \\
\hline $\begin{array}{l}\text { Any efficacy or efficiency tests/data } \\
\text { of such biopesticides? }\end{array}$ & $\begin{array}{l}\text { - Biopesticides exclude the mineral pesticides } \\
\text { - } 50 \% \text { increase of immunity by biopesticides } \\
\text { - Tests confirmed the claim of manufacturers }\end{array}$ \\
\hline $\begin{array}{l}\text { Any toxicological tests/data of these } \\
\text { biopesticides? }\end{array}$ & - Biopesticides are harmless. They increase immunity of plants and soil. \\
\hline $\begin{array}{l}\text { Biosafety issues associated with } \\
\text { biopesticides and ways of tackling }\end{array}$ & - No response \\
\hline \multicolumn{2}{|c|}{ Identification and Characterization of Barriers in Registration and Certification Process } \\
\hline $\begin{array}{l}\text { Detailed procedures of registration } \\
\text { of manufacturing, import, trade/ } \\
\text { sale, transport, storage, disposal, etc. } \\
\text { of biofertilizers and biopesticides }\end{array}$ & $\begin{array}{l}\text { - Lack of adequate legal framework } \\
\text { - Corruption } \\
\text { - Phytosanitary data required } \\
\text { - Absence of well-timed terms on all stages of obtaining permits. } \\
\text { - Absence of procedures of registration of biofertilizers, registration of enterprise, and obtaining } \\
\text { - Termits. } \\
\text { required. They are hard to maintain. } \\
\text { - Lengthy procedure of registration ( } 1 \text { year almost, sometimes }>2 \text { years) } \\
\text { - Until 2009, biofertilizers were not required registration. From July 2015, registration required } \\
\text { for plant growth promoters. } \\
\text { - Registration of business, permit from Fire Department, waste disposal clearance } \\
\text { - Assistance of a professional lawyer is essential. Otherwise, registration process takes longer } \\
\text { - time. } \\
\text { - Sanitary passport for warehouse } \\
\text { - Copy of Instructions for labour protection } \\
\text { - Compliance for commercial premises and documents showing ownership } \\
\text { - Copy of extract from the USREO register (Unified State Register of Enterprises and } \\
\text { - Organization of Ukraine) } \\
\text { - Lease contract and statute } \\
\text { - Letter of guarantee for disposal of toxic waste } \\
\text { - Copies of Employees' diploma } \\
\text { - Registration also done of individual entrepreneur } \\
\text { - Bank statements and tax compliance }\end{array}$ \\
\hline $\begin{array}{l}\text { What kind of laboratory tests or } \\
\text { efficacy tests are required? }\end{array}$ & - Quality certificates, test report, evaluation by experts, document of workers and premises \\
\hline $\begin{array}{l}\text { Documents, preparations, facilities, } \\
\text { compliances, etc. required at the } \\
\text { time of applying for registrations }\end{array}$ & $\begin{array}{l}\text { - Inclusion into the state plan of tests } \\
\text { - Test reports of biological, toxicological and ecological tests } \\
\text { - Registration of biofertilizer enterprise } \\
\text { - Retailers need to acquire certification from producer company } \\
\text { - International products need certificates of those producer companies }\end{array}$ \\
\hline $\begin{array}{l}\text { Detailed account of barriers at each } \\
\text { step of the registration process }\end{array}$ & $\begin{array}{l}\text { - Corruption } \\
\text { - No set procedure of registration of biofertilizers } \\
\text { - No time-bound procedure } \\
\text { - To obtain toxico-hygienic passport of a biofertilizer a scientific institution is approached. } \\
\text { - Frequency of commission meetings is less ( } 3 \text { times a year), which gives clearance to permits. } \\
\text { - Unofficial charges of the registration are higher } \\
\text { - Complexity of registration process of biofertilizers }\end{array}$ \\
\hline
\end{tabular}




\begin{tabular}{|c|c|}
\hline $\begin{array}{l}\text { How are biologicals treated vis-à-vis } \\
\text { chemicals? }\end{array}$ & $\begin{array}{l}\text { - Terminology of biopesticide legislation should be changed. Classification of a product as one } \\
\text { belong to group of pesticides at once complicates the process of obtaining permits. }\end{array}$ \\
\hline $\begin{array}{l}\text { Detailed analysis of costs involved in } \\
\text { all steps of registrations and associ- } \\
\text { ated preparations, compliances, etc. }\end{array}$ & $\begin{array}{l}\text { - Time should be treated a big cost } \\
\text { - Time period is } 30 \text { days for obtaining license without help of lawyer } \\
\text { - Official fee is UAH } 1378 \text {. But, through engaging legal firm, the cost increases to UAH } 3500 \text { or } \\
\text { more } \\
\text { - Cost increases } 3-4 \text { times }\end{array}$ \\
\hline Barriers in licensing processes & $\begin{array}{l}\text { - License is required for plant growth stimulators only [most companies do not declare their } \\
\text { products as 'growth stimulators' because the procedure of registration is complex and costlier.] } \\
\text { - License is mostly required storing the plant growth stimulators } \\
\text { - License is issued by Ministry of Agrarian Policy and Food } \\
\text { - Registration process of biofertilizers and biopesticides is very complicated, compared to the } \\
\text { process of import of Chinese mineral fertilizers, which are of inferior quality. } \\
\text { - Online stores work under permit of manufacturers } \\
\text { - Simplification of registration process is required. } \\
\text { - Lot of paperwork is required during registration process. }\end{array}$ \\
\hline $\begin{array}{l}\text { Difficulties in execution of registra- } \\
\text { tion conditions and license liabilities }\end{array}$ & $\begin{array}{l}\text { - Difficulty in obtaining permits. Procedures are not very clear. } \\
\text { - No set procedure of registration } \\
\text { - Terms should be set for issuing the toxicological passport } \\
\text { - Certificate of state is required certifying the producer of product, manufacturer of active ingredi- } \\
\text { ent, types and values of containers, sphere and conditions of use, and so on. }\end{array}$ \\
\hline
\end{tabular}

of a lawyer is officially 30 days, in reality it takes much longer." (Table 2). According to them, the official fee is UAH 1378; however, when the cost to engage a lawyer is factored in, this amount increases to UAH 3500 or more (Table 2). Indeed, some of the participants stated that this cost increases three to four times (Table 2).

Most companies do not label their products as 'growth stimulators' because the registration procedure is complex and costly (Table 2). The process of registering biofertilizers and biopesticides is very complicated compared to the process for importing Chinese mineral fertilizers or chemical pesticides (which are of inferior quality) (Table 2). In light of these factors, simplification of the registration process is required (Table 2).

The participant manufacturers/suppliers also identified miscellaneous difficulties in the execution of registration conditions and license liabilities (Table 2). According to them, the procedures are unclear, and these procedures of registration need to be changed (Table 2). Therefore, terms should be set for the issuance of the toxicological passport, since a certificate of State is required certifying the producer of the product, the manufacturer of the active ingredient, types and values of containers, and the conditions of use, among other things (Table 2).

\section{Conclusion}

In Ukraine, significant barriers in the business of biologicals include the lack of an adequate legal framework, corruption, the absence of a registration procedure for biofertilizers, and difficulties in obtaining permits. A large amount of data pertaining to biological, toxicological, ecological and phytosanitary parameters is required during the registration process, along with a toxico-hygiene passport, phytosanitary and epidemiological data, bioassays and immunological tests. These tests are extremely difficult to undertake. Moreover, the list of required documents is long. Other reported barriers include the lack of a set procedure for the registration of biofertilizers, no time-bound procedure, higher unofficial charges for registration, and the complexity of the registration process. The costs involved at all steps of the complicated registration process are high, and it is simpler to import Chinese mineral fertilizers or chemical pesticides. Conclusively, barriers make it hard to manage the registration, licensing and trade of biologicals in Ukraine.

\section{References}

1. ANISHCHENKO, I. - LAPA, S. - CEPOI, L. - VOLOSHCHUK, N -, BONDAR, T. - KOSHEVSKYI, I.I. - GONCHARENKO, N. GRYGANSKYI, A. P. and KABALUK, J.T. 2010. Ukraine, Russia and Moldova. In Kabaluk, J. Todd, Antonet M. Svircev, Mark. S. Goettel, and Stephanie G. Woo (ed.). 2010. The Use and Regulation of Microbial Pesticides in Representative Jurisdictions Worldwide. IOBC Global, 99pp. Available online: http://www.IOBC-Global. org

2. EARTH ALIVE. 2017. Earth Alive's Commitment to Sustainable Development, (available online): http://earthalivect.com/aboutus/sustainability/. Accessed on 18 January 2017.

3. KUMAR, S., SINGH, A. 2014. Biopesticides for integrated crop management: environmental and regulatory aspects. J Fertil Pestic, 5 .

4. ROYCHOWDHURY, D., PAUL, M., BANERJEE, S.K. 2014. A Review of the Effects of Biofertilizers and Biopesticides on Rice and tea Cultivation and Productivity. In International Journal of Science, Engineering and Technology, 2(8).

5. URS, A. 2015. The sorry tale of biopesticides. Business Standard, September 21, 2015. 


\section{Agrárne}

\section{Appendix}

\begin{tabular}{lll}
\multicolumn{2}{c}{ Appendix 1: List of Group 2 Participants (Manufacturers and Suppliers of Biofertilizers and Biopesticides) } \\
M.1 & Roman Yuriovich & OOO FuTech, Kharkiv (Kharkiv Region) \\
M.2 & Alexander Nikolaivich & Rokosan TOB 'Green Service Group', Kharkiv \\
M.3 & Ivan Vladimirovich & Life Force (Power of Healthy Earth), Kharkiv (Kharkiv Region) \\
M.4 & Ivan Volodymirovich & Life Force Ukraine, Kharkiv (Kharkiv Region) \\
M.5 & & Agro Shop - Sad Ogorod, Chuguev district (Kharkiv Region) \\
M.6 & Dmitriy Anatolievich & Organic Farming Club, Kharkiv (Kharkiv Region) \\
M.7 & Vitaliy & Zemlya, Kharkiv (Kharkiv Region) \\
M.8 & Maxim Vitaliyevich & AMAI Group, Kharkiv (Kharkiv Region)
\end{tabular}

Appendix 2: List of Group 3 Participants (Government Officers)

O.1 Lobodzec Jaroslav, Head of Plant Protection Department, Lvivska Region, Lviv

O.2 Yaroslav Novitsky, Raiyon Chief of Agriculture, Kosiv (Ivano-Frankivsk Region)

O.3 Igor Honcharenko, Inspector of Agriculture, Kharkiv Region

O.4 Dr. Buchatsky Leonid Petrovych, Ministry of Ecology and Natural Resources, Kyiv

O.5 Vasyl Rafalskiy, Deputy Head of Registration Department, Ministry of Ecology and Natural Resources, Kyiv

O.6 Tetiana Chuchko, Permaculture Expert, Lviv

O.7 Dr. Gu Humeniuk Vasyl, Officer for Agrarian Development, Dolyna Raiyon, Ivano-Frankivsk Region

O.8 Victoria Viktorivna Chaykovska, Deputy Head of Department of Handling Pesticides \& Agrochemicals, Ministry of Ecology and Natural Resources, Kyiv

Appendix 3: Questions for Government Officers (Semi-Structured Interviews and Informal Discussions)

Documentation and Analysis of Microbial Product Registration Procedures in Ukraine

- $\quad$ Acquisition and collection of documents concerning the registration process of biofertilizers and biopesticides

- $\quad$ Review and analysis of registration processes

- $\quad$ Earmarking of grey areas where further investigations are needed

- $\quad$ Analysis of dispute cases

\section{Hasrat Arjiumend}

\section{Contact address/ Kontaktná adresa}

Senior Legal Research Fellow, Centre for International Sustainable Development Law, Montreal (Quebec) H3A 1X1, Canada, e-mail: harjjumend@gmail.com,

Former Mitacs Elevate Fellow, Faculté de droit, Université de Montréal, Montreal (Quebec), Canada

\section{Konstantia Koutouki}

Professor, Faculty of Law, Université de Montréal, Montreal (Quebec)

H3T 1J7, Canada,

e-mail: konstantia.koutouki@umontreal.ca,

Lead Counsel, CISDL \& President, Nomomente Institute, Montreal

(Quebec), Canada

\section{Anatoly Getman}

Professor of Environmental Law \& Vice Rector, Yaroslav Mudryi National Law University of Ukraine, 77, Pushkinskaya St., 61024, Kharkiv,

Ukraine,

e-mail: prorector_navr@nulau.edu.ua

\section{Olga Donets}

Associate Professor, Department of Environmental Law, Yaroslav Mudryi National Law University, 61024, Pushkins'ka St, 77 Kharkiv, Ukraine, e-mail: olya.donets@gmail.com

\section{Acknowledgment}

The authors acknowledge the funding support provided for this research by Mitacs (grant number IT09485) and Earth Alive Clean Technologies, Inc.

The authors also acknowledge the Ethical Approval Certificate (no. CPER-17-114-P) issued by the Multi-Faculty Committee on Research Ethics (Comité plurifacultaire d'éthique de la recherche - CPER)

of Université de Montréal to conduct this research involving different participants. Department of Environmental Law and Department of Land Law of Yaroslav Mudriy National Law University of Ukraine needs special thanks for their academic and logistic support in conducting field works. 